\title{
ОСВІТНІЙ КУРС ЄВРОПЕЙСЬКОЇ ТИРЕОЇДНОЇ АСОЦІАЦІЇ (ЕТА), М. КИЇВ, 13.04.2018 Р. ТЕЗИ ДОПОВІДЕЙ
}

13 квітня 2018 року в м. Києві відбувся масштабний захід, присвячений менеджменту захворювань щитоподібної залози - освітній курс Thyroidmeeting. Організатором заходу виступила компанія Берлін-Хемі, а спікерами відомі вітчизняні та зарубіжні фахівці в галузі діагностики і лікування патології щитоподібної залози.

Про вплив гіпотиреозу на перебіг вагітності і здоров'я дітей, народжених від матерів із субклінічним гіпотиреозом (СГ), розповів у своїй доповіді професор ендокринології, завідувач відділення Ендокринологічної Університетської клініки Сент-П'єр (Брюссель, Бельгія) Кріс Попп (Kris Poppe). Він зазначив, що, незважаючи на відсутність даних про ефективність і доцільність організації універсального скринінгу на гіпотиреоз серед всіх жінок, деякі автори наполягають на його проведенні з огляду на значний позитивний ефект від лікування левотироксином, надто в групі жінок $з$ недостатнім споживанням йоду. Особливо 3 урахуванням того, що скринінг в популяції здорових жінок, виявив гіпотиреоз у третини з них.

Професор ендокринології, директор аспірантури 3 ендокринологіi та обміну речовин Університету Інсубрії (Варезе, Італія) Луїджі Барталена (Luigi Bartalena) зупинився на проблемі менеджменту пацієнтів з ендокринною офтальмопатією (ЕО). Було зазначено, що сьогодні в лікуванні даної патології необхідно спиратися на рекомендації 2016 року ETA/EUGOGO (Європейської тиреоїдної асоціації / Європейської групи з вивчення орбітопатії Грейвса). Вибір терапії у пацієнтів з ЕО залежить від активності і тяжкості захворювання. Згідно з рекомендаціями EUGOGO, при легкій формі EO переважно виключаються фактори ризику та проводиться місцеве лікування. Також при легкій формі ЕО рекомендується прийом селену протягом 6 місяців, який запобігає прогресуванню до тяжкої форми. Першою лінією терапії помірної та тяжкої ЕO $\epsilon$ внутрішньовенна пульс-терапія глюкокортикостероїдами (ГКС). Використовується метилпреднізолон в кумулятивній дозі 4,5 г. Більш високі дози рекомендуються в якості резервної терапії або в дуже тяжких випадках. Друга лінія терапії помірної та тяжкої ЕО - це повторний курс ГКС у високих дозах, можливо, в поєднанні 3 опроміненням орбітальної зони, або поєднання пероральних ГКС із циклоспорином.

Лоуренс Леенгардт (Laurence Leenhardt), професор ендокринології, керівник відділення тиреоїдних i ендокринних новоутворень Інституту раку ЕЗМ (шпиталь Пітьє Сальпетрієр, Університет П'єра та Марії Кюрі, Париж, Франція) озвучила основні зміни в менеджменті раку щитоподібної залози (РщЗ) відповідно до міжнародних консенсусів. У першу чергу, був відзначений факт зміни гістологічної класифікації РЩ3 (2017 рік), в якій змінився статус граничних пухлин. Було наголошено, що супресивна терапія раку повинна бути адаптована залежно від відповіді на лікування. У пацієнтів з радіойодрефрактерним Рщ3 перспективним може бути застосування інгібіторів тирозинкінази.

Професор медицини та ендокринології медичного центру Гутенбергського університету (Майнц, Німеччина) Джордж Дж. Кахалі (George J. Kahaly) озвучив основні принципи ведення пацієнтів 3 гіпотиреозом. Було зазначено, що гіпотиреоз можна розподілити на первинний, вторинний, центральний і периферичний. Етіологія цих форм різна, і при пошуку причини необхідно спиратися не тільки на рівень тиреотропного гормону (ТТГ), але і Т4. При різному їх поєднанні (підвищений/нормальний ТТГ і підвищений/ нормальний Т4) можна легко визначити найбільш ймовірну причину захворювання. Також були дані докладні рекомендації по веденню пацієнтів з гіпотиреозом в залежності від рівнів ТТГ і Т4, наявності коморбідних станів.

HYPOTHYROIDISM

George J Kahaly, MD, PhD

Johannes Gutenberg University Medical Center, Mainz, Germany 


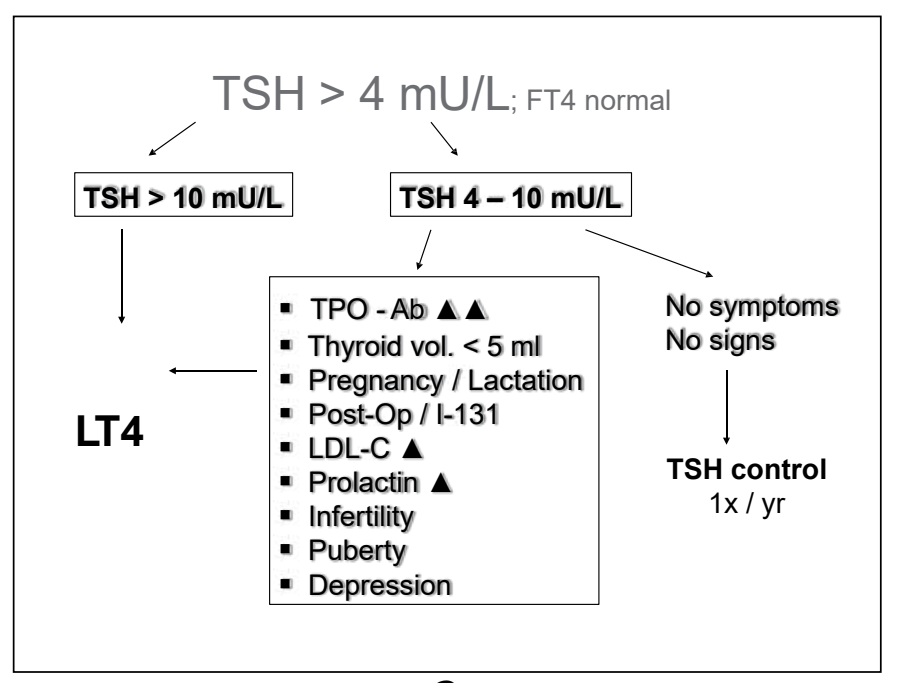

2

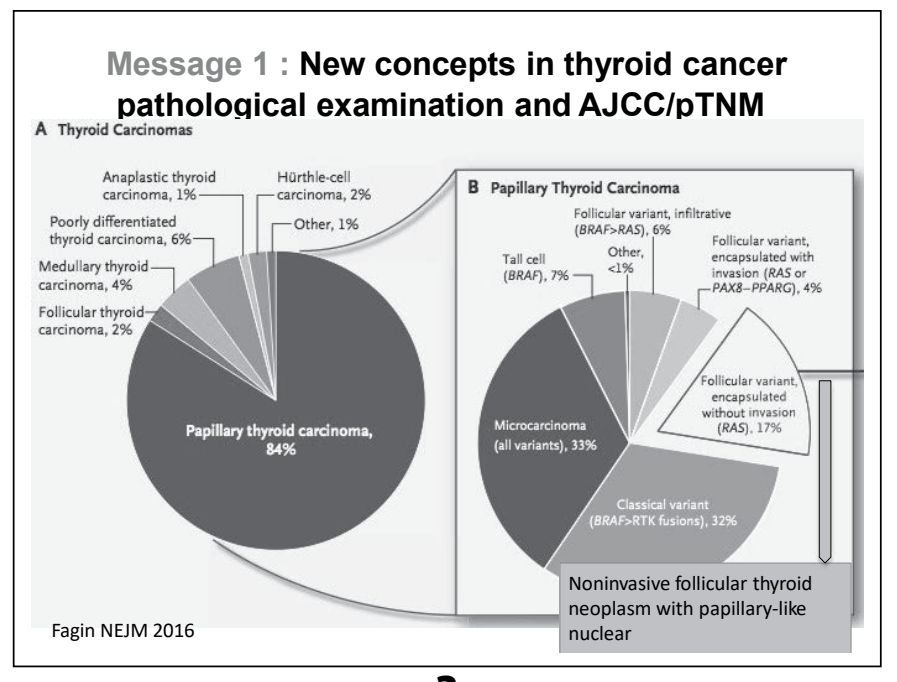

3

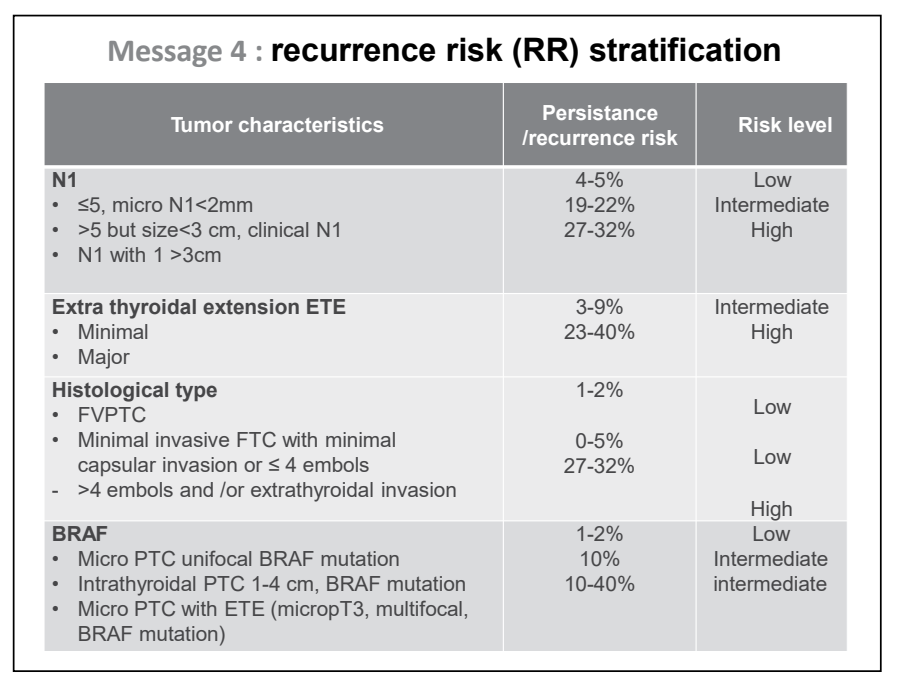

4

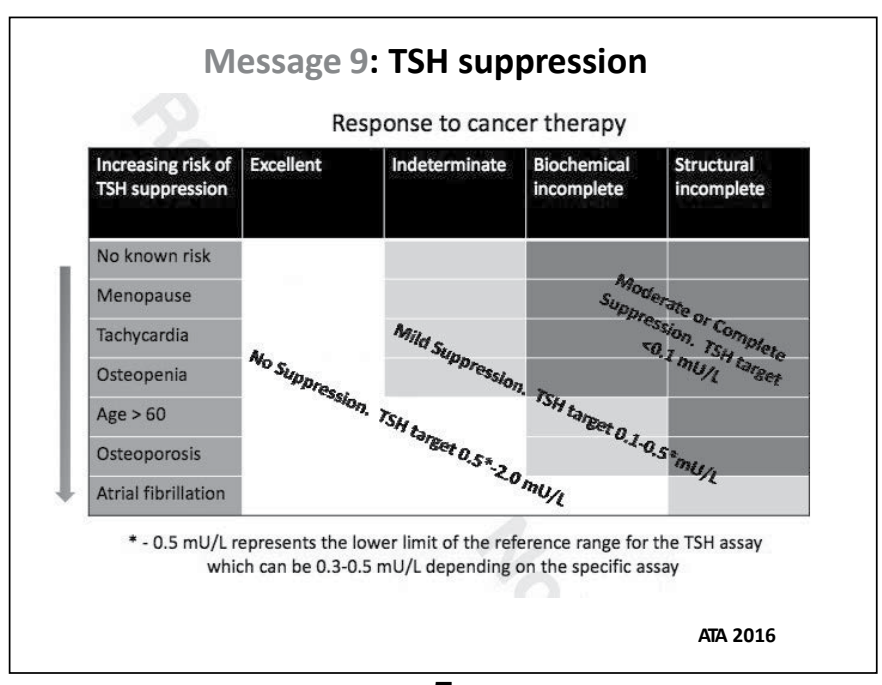

5

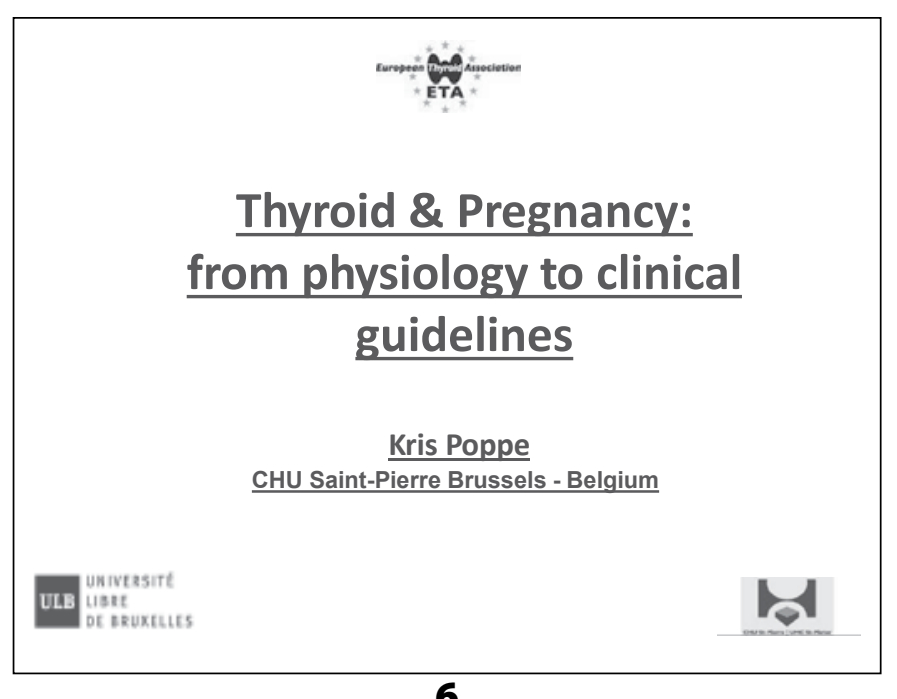

6

Women with a known and treated hypothyroidismandla pregnancy wish

Abalovich et al. Thyroid 2010

when pre-C TSH range was 1.2-2.4 $\mathrm{mIU} / \mathrm{L}, \mathbf{5 0 \%}$ of the patients required an increase in the LT4 dose during pregnancy

when the pre-C TSH was $<1.2 \mathrm{mIU} / \mathrm{L}$, only $17.2 \%$ ( $p<$ 0.02 ) had to increase the LT4 dose during pregnancy 


\section{Pregnant women with a newly discovered hypothyroidism}

\section{- RECOMMENDATION 27}

Treatment of overt hypothyroidism is recommended during pregnancy.

Strong recommendation, moderate-quality evidence.

\section{- LT4 :}

- $\mathrm{TSH}>4.2-10 \mathrm{mU} / \mathrm{L}: 1.42 \mu \mathrm{g} / \mathrm{kg} / \mathrm{day}$

- Hypothyroidism: $2.33 \mu \mathrm{g} / \mathrm{kg} /$ day

Abalovich $\mathrm{M}$ et al. Adequate levothyroxine doses for the treatment of hypothyroidism newly discovered during pregnancy Thyroid 2013

\section{8}

Should women with subclinical hypothyroidism $(\mathrm{SCH})$ be treated in pregnancy?

\section{Treatment cut-offs for TSH:}

TPOab positive

$>$ reference range:

$>2.5 \mathrm{mIU} / \mathrm{L}$ but $<$ reference range:

$<2.5 \mathrm{mIU} / \mathrm{L}$

L-T4 recommended L-T4 may be considered No

\section{TPOab negative}

$>10 \mathrm{mIU} / \mathrm{L}$ :

$>$ reference range but $<10 \mathrm{mIU} / \mathrm{L}$ :

within reference range:

L-T4 recommended L-T4 may be considered No

\section{9}

What is the biochemical goal when treating hypothyroidism in pregnant women?

\section{- RECOMMENDATION 32}

In parallel to the treatment of hypothyroidism in a general population, it is reasonable to target a TSH in the lower half of the trimester-specific reference range. When this is not available,_it is_reasonable, to target maternal TSH concentration $\$$ below $2.5 \mathrm{mU} / \mathrm{L}_{\mathrm{s}}^{\mathrm{L}}$

Weak recommendation, moderate-quality evidence.
How should women with hypothyroidism or at risk forhypothyroidism be monitored through pregnancy?

\section{- RECOMMENDATION 33}

Women with overt and subclinical hypothyroidism (treated or untreated) or those at risk for hypothyroidism (e.g., patients who are euthyroid but TPOAb or TgAb positive, post-hemithyroidectomy, or treated with radioactive iodine) should be monitored with a serum TS $\overline{\mathrm{S}}$ measurement approximately_every 4 weeks until midgestation and at least once near 30 weeks gestation.

Strong recommendation, high-quality evidence.

\section{1}

\section{Thyroid Eye Disease}

\author{
Luigi Bartalena \\ University of Insubria
}

12

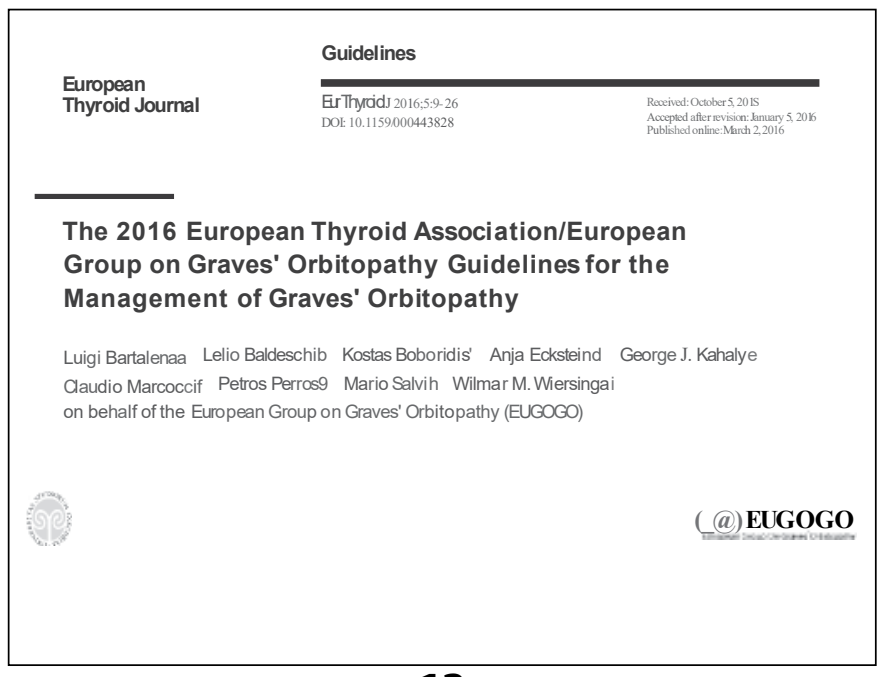

13 
RAI may cause progression/development of GO, but.....

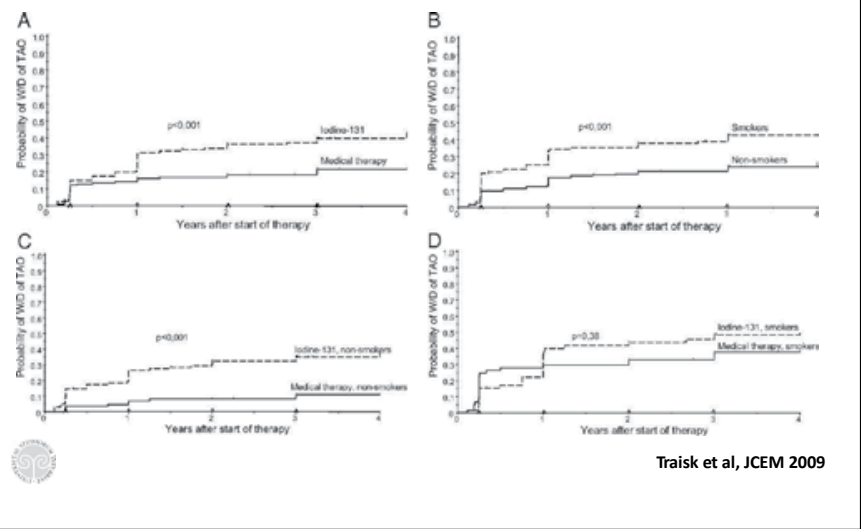

14 ...steroid prophylaxis can prevent it

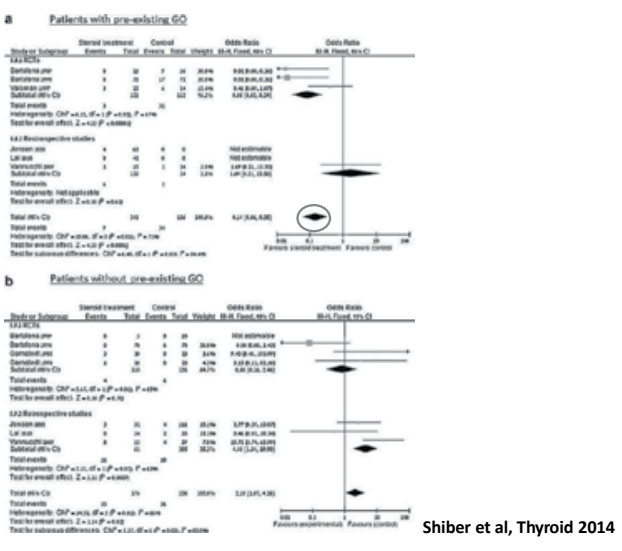

15

IVGC cumulative dose and rate of adverse events (AE)

\begin{tabular}{|c|c|c|c|c|}
\hline & $<3 \mathrm{~g}$ & $\mathbf{3 - 4 . 9} \mathrm{g}$ & $\mathbf{5 - 8} \mathrm{g}$ & $>\mathbf{8 g}$ \\
\hline $\mathrm{N}$. of AE & $18 / 117$ & $35 / 156$ & $63 / 145$ & $86 / 131$ \\
\hline$\%$ of AE & 15.4 & 22.4 & 43.4 & 65.6 \\
\hline Minor & 15 & 26 & 49 & 60 \\
\hline Moderate & 2 & 9 & 13 & 20 \\
\hline Severe & 1 & 0 & 1 & 6 \\
\hline
\end{tabular}

Zang, J Endocrinol Invest 2011
IVGC single daily dose and rate of adverse events (AE)

\begin{tabular}{|c|c|c|}
\hline & $0.5 \mathrm{~g}$ & $1 \mathrm{~g}$ \\
\hline N. of AE & $34 / 132$ & $23 / 41$ \\
\hline$\%$ of AE & 28 & 56 \\
\hline Minor & 46 & 34 \\
\hline Moderate & 20 & 46 \\
\hline Severe & 0 & 1 \\
\hline
\end{tabular}

Zang, J Endocrinol Invest 2011

17

\section{Recommendation 11}

We recommend that the cumulative dose of intravenous GCs should not exceed 8 grams and that GO patients with evidence of recent viral hepatitis, significant hepatic dysfunction, severe cardiovascular morbidity ir psychiatric disorders should not be administered intravenous GCs; diabetes and hypertension should be well controlled before starting treatment

$>$ Strength of Recommendation:1; Evidence: $\varnothing \emptyset \circ 0$

18

Potential novel treatments targeting TSHR or IGF-1R

\begin{tabular}{|c|c|c|c|c|}
\hline Agent & Type & $\begin{array}{l}\text { Mechanism of } \\
\text { action }\end{array}$ & Advantages & Disadvantages \\
\hline $\begin{array}{l}\text { Ab 5C9 } \\
\text { Ab Ki-70 }\end{array}$ & $\begin{array}{l}\text { Monoclonal } \\
\mathrm{Ab}\end{array}$ & $\begin{array}{l}\text { TSHR-blocking } \\
\text { Ab }\end{array}$ & $\begin{array}{l}\text { - Inverse agonist } \\
\text {-High affinity } \\
\text { - Long half-life }\end{array}$ & Parenteral route \\
\hline $\begin{array}{l}\text { ANTAG2 } \\
\text { ANTAG3 }\end{array}$ & $\begin{array}{l}\text { Small } \\
\text { molecule }\end{array}$ & $\begin{array}{l}\text { TSHR-blocking } \\
\text { activity }\end{array}$ & $\begin{array}{l}\text {-Inverse agonist } \\
\text { - Oral route }\end{array}$ & Short half-life \\
\hline Teprotumumab & $\begin{array}{l}\text { Monoclonal } \\
\mathrm{Ab}\end{array}$ & $\begin{array}{l}\text { IGF-1R-blocking } \\
\mathrm{Ab}\end{array}$ & $\begin{array}{l}\text {-Phase } 2 \text { clinical trial in } \\
\text { GO } \\
\text {-Long half-life }\end{array}$ & $\begin{array}{l}\text {-Parenteral route } \\
\text {-Non specific for } \\
\text { GO }\end{array}$ \\
\hline Linsitinib & $\begin{array}{l}\text { Small } \\
\text { molecule }\end{array}$ & $\begin{array}{l}\text { IGF-1R-blocking } \\
\text { activity }\end{array}$ & $\begin{array}{l}\text {-Phase } 3 \mathrm{CT} \text { for } \\
\text { adrenocortical ca. } \\
\text {-Phase } 2 \mathrm{CT} \text { for lung, } \\
\text { ovarian, and prostate } \\
\text { ca. } \\
\text { - Oral administration }\end{array}$ & $\begin{array}{l}\text {-Short half-life } \\
\text { - Non-specific for } \\
\text { GO } \\
\text { - Unknown effect } \\
\text { on GO }\end{array}$ \\
\hline & & & \multicolumn{2}{|c|}{ From Neumann et al, Horm Metab Res, 2015} \\
\hline
\end{tabular}

19 


\section{Take Home Messages}

$\checkmark$ The incidence and the prevalence of GO, particularly moderate-to-severe, are declining lately

$\checkmark$ A better interaction between GPs, ophthalmologists and endocrinologists is essential for early diagnosis and treatment

$\checkmark$ Effective actions on modifiable risk factors are fundamental

$\checkmark$ Mild GO usually requires a wait-and-see strategy, local measures and a course of selenium supplementation

$\checkmark$ Intravenous glucocorticoids are the first-line treatment for moderate-tosevere and active $\mathrm{GO}$

$\checkmark$ Novel biologicals have provided promising results

\section{0}

\section{Йодний дефіцит в Україні \\ В.І. Паньків, д. мед. н., проф.}

Український науково-практичний чентр ендокринної хірургії, трансплантації ендокринних органів і тканин МОЗ України, м. Київ.

За умов природного дефіциту йоду проживає близько 2 млрд. людей. Відомо, що найбільшу небезпеку становить недостатнє надходження йоду в організм на етапі внутрішньоутробного розвитку і в ранньому дитячому віці. Зміни, спричинені йодним дефіцитом в ці періоди життя, проявляються незворотними дефектами в інтелектуальному і фізичному розвитку дітей.

Однак весь спектр йододефіцитної патології широкий i простягається від репродуктивних порушень до специфічних захворювань щитоподібної залози.

У 96 країнах проблема дефіциту йоду в харчуванні вже вирішена завдяки дії законодавчих і нормативних актів з обов'язкового йодування солі. Тільки 13 країн, які не мають цього закону, в тому числі і Україна, продовжують проживати в умовах некомпенсованого дефіциту йоду.

Медіана йодурії в Україні становить 88 мкг/л, частка сімей, які вживають йодовану сіль - до $25 \%$, частота виявлення зобу у школярів - до 15-30\%. На всій території зберігається йодний дефіцит легкого ступеня, лікарські препарати йоду в групах підвищеного ризику розвитку йододефіцитних розладів (ЙДЗ) не використовуються у повному об'ємі, використання йодованої солі носить добровільний характер.

Мало хто звернув увагу на те, що якось непомітно виповнилося 15 років 3 офіційного відродження програми йодної профілактики в пострадянській
Україні. 26 вересня 2002 р. Кабінет Міністрів України прийняв Постанову №1418 «Про затвердження Державної програми профілактики йодної недостатності у населення України на 2002-2005 роки». На жаль, основні її положення так і не були втілені в життя, а нова програма досі не розроблена. Крім відсутності нормативно-правової бази для створення державної системи масової йодної профілактики, перешкодами на шляху реалізації в Україні профілактичних заходів $\epsilon$ низький рівень інформованості населення та широкого кола медичних працівників 3 питань поширеності дефіциту йоду та тих негативних наслідків, до котрих він призводить.

Ще одна вікова група належить до високого ризику по формуванню ЙД3, а саме жінки фертильного віку, які планують вагітність. Підтвержденням слугують отримані нами дані про функціональний стан щ3 в цієї групи населення на тлі здійснюваної йодної профілактики. Встановлено, що практично у кожної четвертої жінки з нормальними розмірами щЗ (у $27 \%$ випадків), і в кожної третьої жінки, що має 306 (у $32 \%$ випадків), виявляють хронічну асимптоматичну гіпотироксинемію, яка в прегравідарному періоді загрожує порушенням репродуктивної функції жінки, а зачаття на тлі асимптоматичної гіпотироксинемії - погіршенням ментального статусу потомства.

Йодну профілактику слід призначати на етапі прегравідарної підготовки і продовжувати під час вагітності і в період лактації у вигляді препаратів йодиду калію в дозі 200 мкг/добу.

Вагітним жінкам не слід призначати йодовмісні біологічно активні добавки з метою індивідуальної йодноїпрофілактики.Носійствоантитілдотиреоїдної пероксидази не вважається протипоказанням до призначення йодиду калію, хоча і потребує динамічного контролю функції щитоподібної залози впродовж вагітності.

У 2017 р. в Україні затверджено нові норми фізіологічних потреб населення в основних харчових речовинах та енергії (наказ МОЗ України від 03.09.2017 р. № 1073). Потреба в йоді вагітних та жінок, що годують грудьми, складається з 150 мкг норми вживання здоровою дорослою людиною та 200 мкг додаткового надходження йоду для забезпечення перебігу фізіологічної вагітності та екскреції йоду в грудне молоко під час лактації.

Поява альтернативних засобів, які позиціонують для лікування і профілактики дефіциту йоду на території України, має аналізуватися насамперед 3 
наукової точки зору. Це важливо, оскільки боротьба з дефіцитом йоду - це система заходів, в ході яких все населення країни, включаючи дітей, підлітків, вагітних жінок і літніх людей, має бути забезпечено адекватною кількістю йоду. Тобто будь-які засоби, які застосовуються для цього, повинні бути перш за все безпечними, а їх використання має бути контрольованим.

Подібний підхід у всьому світі відповідає вимогам ВОО3 та базується на критеріях доказової медицини, перевірених багаторічною практикою абсолютної більшості країн світової спільноти. Цим вимогам на сьогоднішній день відповідають йодована сіль i лікарські препарати йоду.

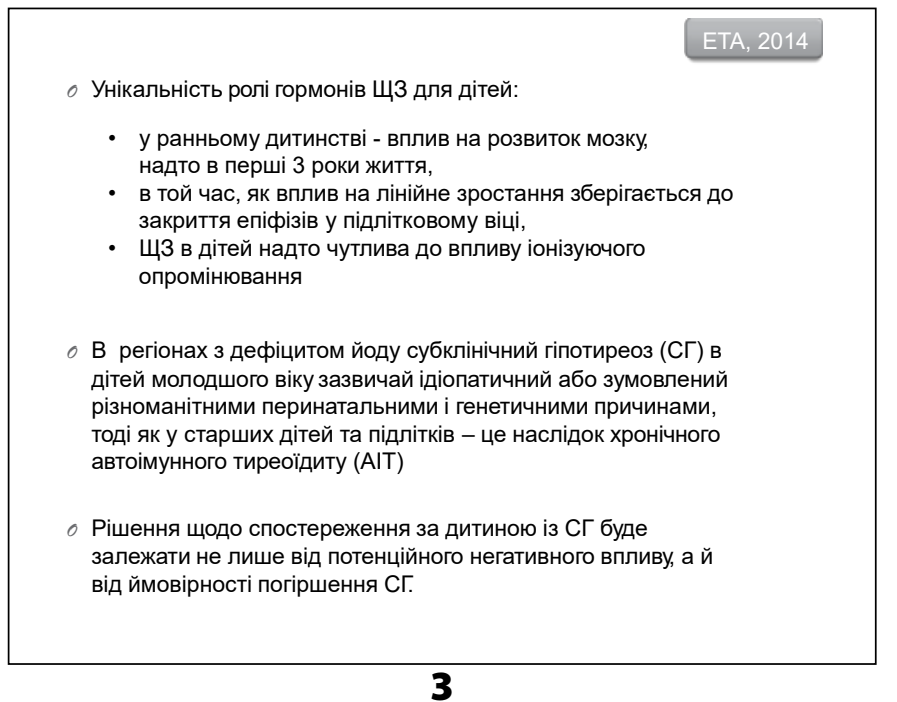

3

\begin{tabular}{c} 
Субклінічний гіпотиреоз в \\
дітей: \\
критерії діагностики і вибору \\
лікування \\
(Настанови Європейської Тиреоїдної \\
Асоціації, 2014 р.) \\
д.мед.н. ЗЕЛІнСьКА Н.Б. \\
Відділ дитячої ендокринології \\
УНПЦЕХ,ТЕОіТ МОЗ України \\
м. Київ, 13 квітня 2018 р. \\
\hline
\end{tabular}

1

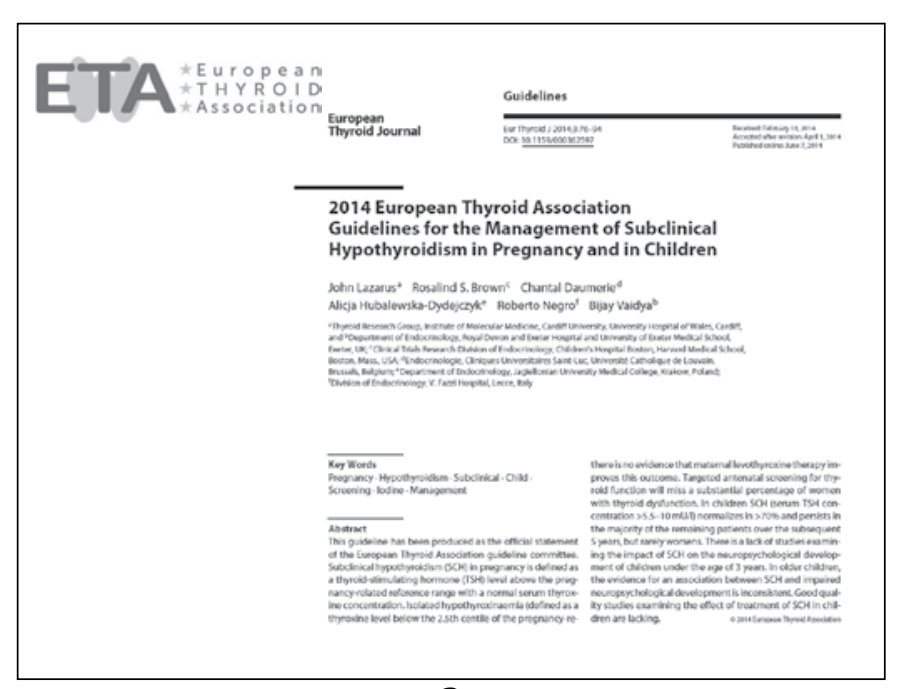

2 


\begin{tabular}{|c|c|}
\hline & ETA, 2014 \\
\hline \multicolumn{2}{|l|}{ 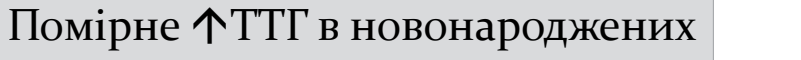 } \\
\hline \multicolumn{2}{|l|}{ о Недоношені } \\
\hline \multicolumn{2}{|l|}{ о Діти, які народились SGA } \\
\hline \multicolumn{2}{|l|}{ о Після ЕКО } \\
\hline \multicolumn{2}{|l|}{ о У осіб з трисомією 21} \\
\hline \multicolumn{2}{|l|}{ о Помірні морфологічн аномалії в розвитку щЗ } \\
\hline \multicolumn{2}{|l|}{$\begin{array}{l}\text { о Генетичний дефрект гормоногенезу (в тч. мутації } \\
\text { в гені рецептора ТТГ, тиропероксидази) }\end{array}$} \\
\hline $\begin{array}{l}\text { Помірне } \text { АТТГ або СГ зберігається у }>30-40 \% \\
\text { таких дітей }\end{array}$ & \\
\hline
\end{tabular}

\section{6}

\section{ETA, 2014}

○ В загальній популяції СГ (ТТГ > 5,5-10 мОД/л)

зникає в $>70 \%$ дітей, у більшості інших

зберігається протягом наступних 5 років, але

рідко погіршується.

○ В пацієнтів з ожирінням ТТГ 5-7 мОД/л,

ймовірно, є наслідком ожиріння, а не його причиною.

o Більшість дітей із СГ не мають симптомів і

ознак явного гіпотиреозу.

○ СГ при синдромі Дауна зустрічається в 10 разів частіше, ніж у загальній популяції.

\section{Рекомендація №27}

Рекомендується регулярний контроль ффункції ЩЗ у пацієнтів з трисомією 21 (доказовість 2S)

\section{7}

\section{СГ i XAIT}

口 Неавтоімунний «ідіопатичний» $\mathrm{C}$, виявлений при $\mathrm{HC}$ чи у в подальшому дитинстві, $є$ гетерогенним захворюванням, яке минає у $58 \%$ (36-88\%) пацієнтів, або зберігається, проте тільки у $\approx 10 \%$ погіршується протягом наступних 8 років.

- СГ в дітей $>8$ років та у підлітків частіше спричинений XAIT

\section{Рекомендація №26}

У дітей з $\mathrm{Cr}$ віком > 3 років з початковими (-) a/m до щз, показаний регулярний моніторине ТTГ і АТПО. 3 огляду на низький ризик прогресування, моніторине - через 1 рік, якщо не спостерігається погіршення - рідше (доказовість 2S)

\section{Рекомендація №28}

У дітей з СГ + XAIT - ризик прогресування до явного гіпотиреозу. Тому дітям з початковим ТАТПО та / або ТАТТГ слід контролювати ТTГ ( \pm АТПО) кожні 612 міс. Частіше - пацієнтам з початковим ТТГ> 10 мОД/л і яких було прийнято рішення не лікувати. (доказовість 2W)

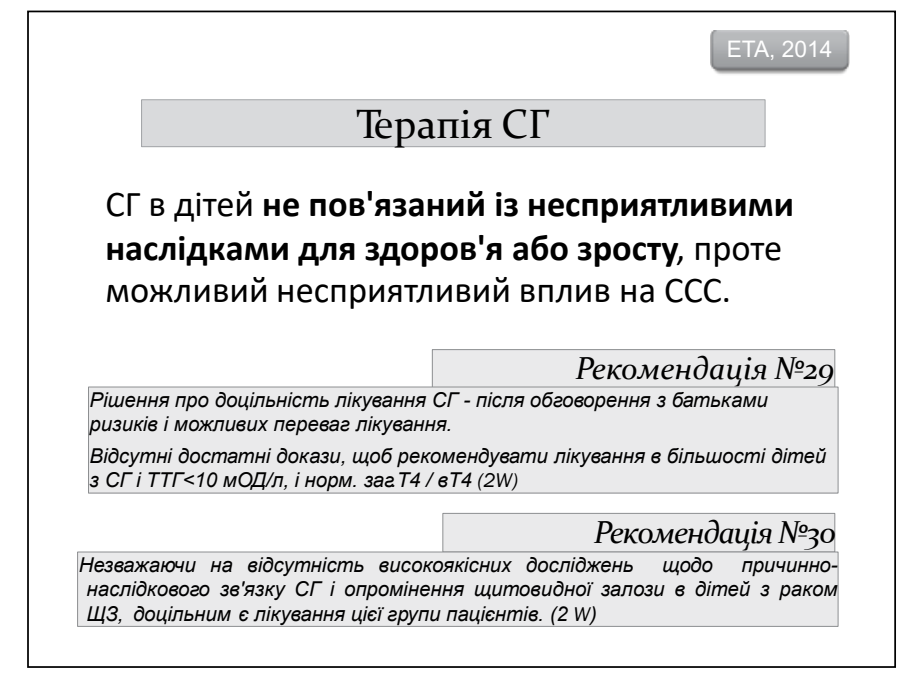

9

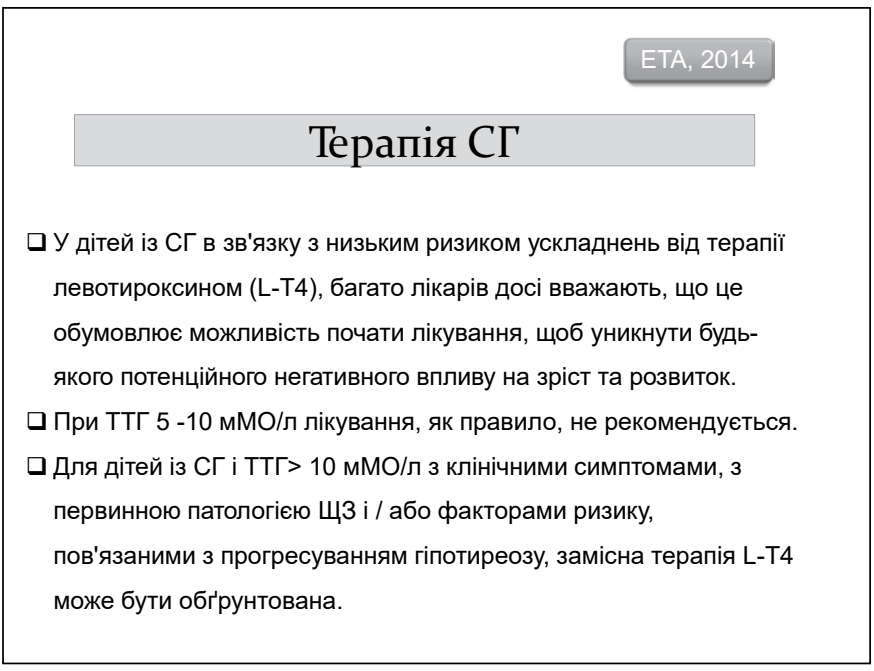

10

\begin{tabular}{|c|c|}
\hline & ETA, 2014 \\
\hline \multicolumn{2}{|c|}{ Терапія СГ } \\
\hline Левотироксин & Мета лікування \\
\hline $\begin{array}{l}\text { 10-15 мкг/кг/добу одразу } \\
\text { після (+) неонатального }\end{array}$ & $\begin{array}{l}\text { T4 > середини норми } \\
\text { педіатричного діапазону }\end{array}$ \\
\hline $\begin{array}{l}\text { результатів аналізів для } \\
\text { підтвердження діагнозу. }\end{array}$ & $\begin{array}{l}\text { ТТГ } \leq \text { середини норми } \\
\text { педіатричного діапазону }\end{array}$ \\
\hline $\begin{array}{l}\text { Більш високі дози } \\
\text { можливі для немовлят } 3\end{array}$ & $\begin{array}{l}\text { Нормалізувати T4 за 2-4 } \\
\text { тижні від початку терапії }\end{array}$ \\
\hline гіпотиреозом & $\begin{array}{l}\text { П Після визначення правильної } \\
\text { дози - контроль ТТГ і Т4 - } \\
\text { кожні 1-2 міс. протягом 1-го } \\
\text { року життя, надалі - рідше. }\end{array}$ \\
\hline
\end{tabular}

\section{1}




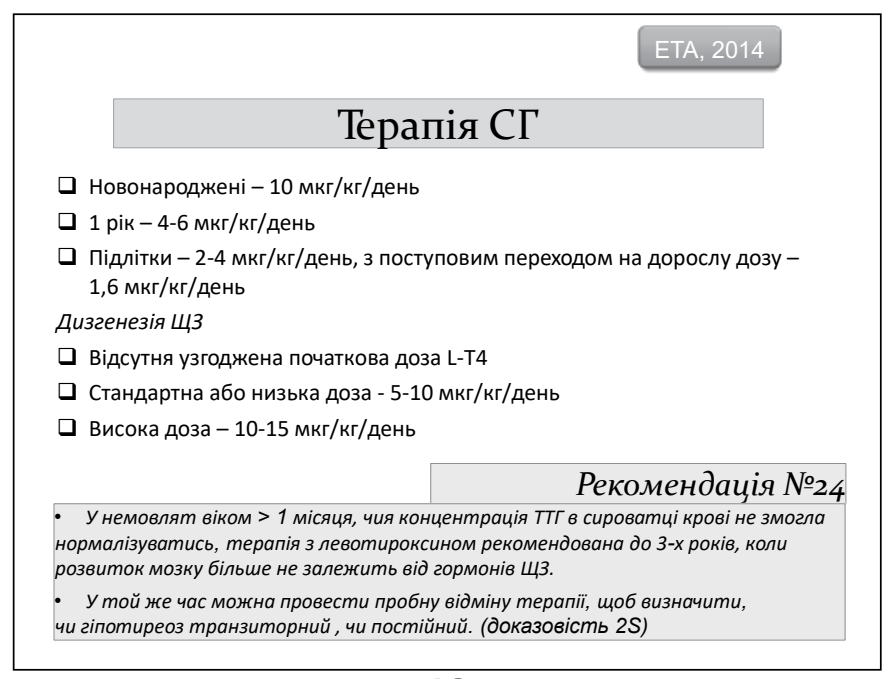

12

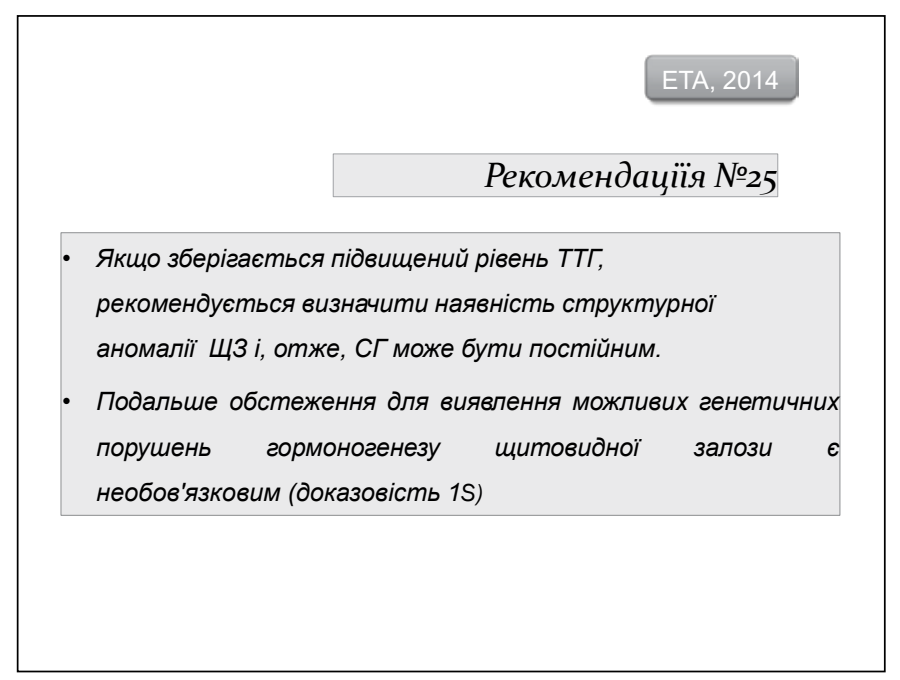

13

\section{Розбір клінічних випадків}

Є.В. Глоба, к. мед. н., ст. наук. співроб.

Український науково-практичний центр ендокринної хірургії, трансплантації ендокринних органів і тканин МОЗ України, м. Київ

В доповіді наведено два клінічних випадки, спільною рисою яких була наявність резистентності до тиреоїдних гормонів.

Синдром резистентності до тиреоїдних гормонів $(\mathrm{RTH}) \epsilon$ спадковим синдромом, що характеризується зниженою чутливістю тканин-мішеней до гормонів щитоподібної залози. RTH вперше був описаний в 1967 році як частина сімейного синдрому, що включає глухонімоту, зоб

і аномально підвищений рівень тиреоїдних гормонів на тлі нормального вмісту тиреотропного гормону (ТTГ) в сироватці крові. Клінічні прояви RTH різноманітні та залежать від локалізації і ступеня функціональної активності мутації в гені TRHB.

Представлений клінічний випадок дитини із синдромом резистентності до тиреоїдних гормонів. При обстеженні у ендокринолога зі скаргами на підвищену емоціональну лабільність були виявлені підвищені рівні вільного Т4 та Т3 на тлі нормального рівня тиреотропного гормону та антитіл до пероксидази та рецептору ТТГ. У зв'язку з тим, що тип успадкування RTH в більшості сімей аутосомнодомінантний, проведене гормональне обстеження у батьків, яке виявило аналогічні зміни тиреоїдних гормонів у батька. Наданий алгоритм диференційної діагностики та сучасні підходи до лікування такого синдрому.

Також був представлений клінічний випадок дитини із псевдогіпопаратиреозом. Ця патологія характеризується порушенням фосфорнокальцієвого обміну, специфічним фенотипом, а також часто супроводжується затримкою фізичного та інтелектуального розвитку. Представлено історію хвороби дитини, яка звернулася до ендокринолога 3 попереднім діагнозом вродженого гіпотиреозу. Описано клінічні прояви захворювання в пацієнтки, етапність їх виникнення, ретроспективну динаміку лабораторних показників на тлі попереднього лікування, результати генетичного дослідження (GNAS1, c.1107_1108del) що дозволило підтвердити діагноз псевдогіпопаратиреозу. Було наголошено на важливості диференційної діагностики порушень фосфорно-кальцієвого обміну у дітей, зокрема 3 ознаками гормональної резистентності.

Також була надана увага генетичним синдромам, що супроводжуються гіпотиреозом та іншою важкою екстратиреоїдною патологією (наприклад, включаючи глухоту, аномалії урогенітального тракту, легеневі захворювання та ін.) з необхідністю вчасної генетичної діагностики таких пацієнтів та медико-генетичного консультування членів сім'ї. 